Original Article

\title{
DNA-BASED HYBRID LIQUID CRYSTALLINE NANO ORGANOMETALLIC COMPOSITES FOR TARGETED DRUG DELIVERY IN NEUTRON CAPTURE THERAPY
}

\author{
SLIVKINA I., KONDRASHINA O. V., HALAHAKOON M. A. J.", BELENOVA A. S.
}

Department of Pharmaceutical Chemistry and Pharmaceutical Technology, Faculty of Pharmacy, Voronezh State University, 394006, Voronezh, Street, Studentcheskaya, 3

Email: amilajh1982@hotmail.com

Received: 28 Feb 2017 Revised and Accepted: 20 Apr 2017

\begin{abstract}
Objective: The aim of this work was focused on the obtaining a DNA-based hybrid nano liquid crystalline organometallic composites for targeted drug delivery in neutron capture therapy.

Methods: The formation of a cholesteric liquid crystalline DNA (CLCD-DNA) dispersion has performed using ultrasonic depolymerized calf thymus DNA(MW-0.6-0.8 $\left.\times 10^{6} \mathrm{Da}\right) 2 \times 10^{-7} \mathrm{M}$, mixing with polyethylene glycol $8.5 \times 10^{-5} \mathrm{M}$, dissolved in the $0.3 \mathrm{M} \mathrm{NaCl}$ solution and incubated over $1,0 \mathrm{~h}$ at 20 ${ }^{\circ} \mathrm{C}$. CLCD-DNA formation process was determined and controlled by measuring absorption value of circular dichroism (CD) spectrum in the range of $350-600 \mathrm{~nm}$. The organometallic DNA-Gd compound was formed by processing the obtained CLCD-DNA with $2.49 \times 10^{-4} \mathrm{M}, 4.97 \times 10^{-4} \mathrm{M}, 9.8 \times 10^{-4}$ $\mathrm{M}, 1.48 \times 10^{-3} \mathrm{M}, 2.92 \times 10^{-3} \mathrm{M} \mathrm{GdCl}_{3}$ aqueous solutions. CLCD-DNA-gadolinium complex formation process was registered over the appearance of $2^{\text {nd }}$ amplitude in the CD spectrum. DNA-Gd complex dispersion toxicity was evaluated over $40 \mathrm{~min}, 24 \mathrm{~h}$ and $72 \mathrm{~h}$ incubation with $1 \times 10^{6} \mathrm{cells}$ in the RPMI-40 medium supplemented with $3 \times 10^{-4} \mathrm{M} \mathrm{Gd}^{3+}$.
\end{abstract}

Results: The obtained CLCD-DNA-Gd (d $\sim 500 \mathrm{~nm})$ particles was shown less toxicity and higher viability percentage of macrophages after 40 min incubation with CLCD-DNA-Gd contains $\mathrm{Gd}^{3+}$ ions concentration $3 \times 10^{-4} \mathrm{M}$ showed $100 \%$ viability and after $72 \mathrm{~h}$ ours approximately $89 \%$. The cells immobilized with CLCD-DNA-Gd particles contains $3 \times 10^{-4} \mathrm{M} \mathrm{Gd}^{3+}$, neutron irritation was caused a $100 \%$ cell deaths.

Conclusion: Obtained relatively stable, non-cytotoxic drug forms with a maximum local concentration of gadolinium ( $400 \mu \mathrm{g} / \mathrm{ml})$. The effectiveness of these nanosystems for targeted drug delivery has markedly superior efficacy than ${ }^{10} \mathrm{~B}$ and other products were based on gadolinium.

Keywords: Nanotechnology, Targeted drug delivery, Nanosystem, Boron neutron capture therapy, Gadolinium (Gd)

(C) 2017 The Authors. Published by Innovare Academic Sciences Pvt Ltd. This is an open access article under the CC BY license (http://creativecommons.org/licenses/by/4.0/) DOI: http://dx.doi.org/10.22159/ijpps.2017v9i6.17991

\section{INTRODUCTION}

Nanotechnology and Nanoengineering emerged from the latest achievements and discoveries in the field of visualization, analysis, and manipulation of nanoscale size structures and the controlled synthesis of new materials $[1,2]$. One of the novels fields of nanotechnology and nanoengineering was called "nanomedicine," which was conscript to make the treatment of many diseases more directed and purposeful (nanotechnological drug delivery system), which was corresponded to the interests of both practitioners and their patients. Nano engineering systems in nanomedicine were allowed to changing the distribution of medications in the body with the possibility of targeted delivery into the affected organ. This objective was achieved by using the nanoparticles those were capable of targeted delivery of drugs taking into account the biochemical characteristics of the organism of the patient. Nanoparticles were enabled to overcome the poor solubility, improve absorption properties (absorbability), and develop the new generations of drugs [3]. The combination of reactivity and tendency to create hierarchical biopolymers nanostructures, as well as the possibility of industrial preparation macromolecule biopolymers were made them a suitable object for use in nanotechnology [1-6].

Neutron capture therapy (NCT) is a modern method of treatment of malignant tumors. It was based on the reaction of thermal neutron capture by the nuclei of some non-radioactive nuclides of some chemical elements. As a result of the nuclear reaction was produced an isotope, the further conversion was accompanied, in particular, the appearance of $\gamma$-radiations, which were caused damage to cells, including transformed [7]. The element, commonly used for the treatment of malignancies, serves as boron, was introduced into the tumor in the form of the chemical compounds as ${ }^{10} \mathrm{~B}$ nuclide. However, the effectiveness of ${ }^{10} \mathrm{~B}$ was poor. Recently, researchers, attention were attracted to special remark of the more promising element gadolinium, having the best biophysical characteristics $[8,9]$. Interaction ${ }^{157} \mathrm{Gd}$ with the thermal neutrons follows the scheme:

$$
\begin{aligned}
& { }^{157} \mathrm{Gd}+\mathrm{n}^{0} \rightarrow{ }^{158} \mathrm{Gd}^{*}+\gamma \text {-Rays+conversion electrons } \rightarrow \\
& \rightarrow{ }^{158} \mathrm{Gd}+\text { Auger electrons+characteristic radiation, }
\end{aligned}
$$

Where, $\mathrm{n}^{\circ}$-neutron, ${ }^{158} \mathrm{Gd}^{*}$-nuclear isomers (an excited state of the nucleus nuclide-158) [9].

${ }^{157} \mathrm{Gd}$ has the largest stable nuclides neutron capture cross-section $\left(2.55 \times 10^{5} \mathrm{Barn}\right), 66$ times greater than ${ }^{10} \mathrm{~B}$, during radiation process $\gamma$-quanta have mileage more than $100 \mu \mathrm{m}$. They can disrupt biochemical processes, influence the tumor cells, even if ${ }^{157} \mathrm{Gd}$ was in the intracellular space [9].

The efficiency of neutron capture therapy depends on the content of gadolinium in the diseased tissue [10]. However, the highly toxic properties of $\mathrm{Gd}^{3+}$ ions even at the very low concentrations was caused complexities in use [11]. At the same time, having a welldeveloped capillary network and, an intense circulation, as a consequence, tumor tissues create obvious difficulties in retaining the therapeutic doses of gadolinium and minimizing its transport throughout the body [12].

The solution to this problem was creating a new generation of biocompatible nanomaterials contains highly stable $\mathrm{Gd}^{3+}$ ion complexes, which can be adhered to the cells effectively. Because of, only the form of the bound (complex) and in the insoluble state of the gadolinium can be administered to patients safely [13]. Consequently, the success of neutron-capture therapy was based on the use of medicinal products containing, a high concentration of the neutron-capture element, and also capable of transferring and maintenance concentration in the affected tissues until exposed to the thermal neutrons irradiation [14]. Highly efficient and nontoxic 
nanoengineering system (nanotechnological drug delivery system), which can maintenance concentration and also effectively delivered gadolinium into the tumor tissues at the necessary times the promising way to solves some problems in NCT using gadolinium [3, $4,7,11,13]$.

\section{MATERIALS AND METHODS}

\section{Apparatus}

In this experiment were used: ultrasonic Disintegrator USDN-2T (Ukrrospribor, Ukraine), atomic emission spectrometer JY-38P (HORIBA Jobin Yvon Ltd., France), fluorescent nanoscope (LLC "Stereonik," Russia), coaxial germanium detector IGC-45 (ORTEC Inc., Oak Ridge, USA), neutron complex NG-400 (Moscow meson factory, INR).

\section{Materials and reagents}

The mice were used in this experiments belong to «Wistar» lines, provided by Shemyakin-Ovchinnikov Institute of Bioorganic Chemistry, RAS (IBCh RAS) in Russia. The experiments carried out with laboratory animals was conducted according to the recommendations of "laboratory manual and alternative models in biomedical technology" in Russia, GLP and under surveillance of the ethical committee of VSU. All chemicals and reagents were of analytical grade and used without further purification. Polymerizeddouble-stranded Calf thymus DNA (Calf Thymus DNA «Sigma » USA) purified from impurities was used in the experiment, polyethylene glycol (Fluka, Switzerland), gadolinium chloride in high-grade purity was produced by "NPF Nevsky Himik" Russia, pure gadolinium foil with $0.11 \mathrm{~mm}$ thickness (ORTEC Inc., Oak Ridge, USA). For the macrophages, isolation procedure was used macrophages medium-RPMI-1640 (Sigma, USA)

\section{General procedures}

\section{The preparation of CLCD DNA-Gd complex}

Depolymerization of DNA was carried out using an ultrasonic Disintegrator USDN-2T. After the depolymerization, the molecular weight of the DNA was measured in a $1 \%$ agarose gel $(0,5-0,8) \times 10^{6}$ Da using the electrophoretic method. The formation of a cholesteric liquid crystalline dispersion of DNA (CLCD-DNA) in polyethylene glycol has performed the procedure described by Y. M. Yevdokimov et al. $[15,16]$. The formation of CLCD DNA was assessed by the presence of an intense negative band in the circular dichroism spectrum at $\lambda-270 \mathrm{~nm}$. The Organometallic hybrid complex of the DNA-Gd was formed by processing the obtained liquid crystal dispersion with an aqueous solution of $\mathrm{GdCl}_{3}$ (fig. 1.).

\section{The method of macrophages separation and viability determination}

Macrophages were isolated from the mice peritoneal cavity. Mice were decapitated, bled, laid on the prepared table in the back stab, the ventral surface was treated with alcohol and cut the skin along the midline of the body. $5.0 \mathrm{ml}$ of Hank's solutions was injected into the peritoneal cavity using a syringe with a fine needle. The mouse abdomen was gently massaged mixing the solution with the viscera over $3 \mathrm{~min}$. After that, using a syringe with a thick needle injected fluid was aspirated and was centrifuged for $5 \mathrm{~min}$ at $1000 \mathrm{rpm}$. The supernatant was removed with a Pasteur pipette, and the remaining cells pellet was diluted with $1.0 \mathrm{ml}$ Hanks solution. The concentration of cells was counted using the Goryaeva chamber. After the cells count, the solution was diluted by adding Hanks solution until the final cell concentration of the solution was reached to $1 \times 10^{6} \mathrm{cells} / \mathrm{ml}$. The viability determination of isolated native macrophages cells was carried out by suspending macrophages in the plastic tubes with medium-RPMI-1640 (Sigma, USA) and was incubated in a $5 \% \mathrm{CO}_{2}$ atmosphere at $37{ }^{\circ} \mathrm{C}$ for $25 \mathrm{~h}$. Macrophage lysates were carried out by three consecutively freezing and thawing cycle [18].

The DNA-Gd dispersed particles adhesion of the cells was determined by $1.0 \mathrm{ml}$ cell suspension incubated in the nutrient medium contain the $3 \times 10^{-4} \mathrm{M}$ of $\mathrm{Gd}^{3+}$ over $40 \mathrm{~min}$. After the incubation process, the cell was washed out with physiological solution three times and was carried out freezing-thawing process, and subsequent separation of cell membranes from the supernatant was done by centrifugation at $1000 \mathrm{rpm}$ over 20 $\min$ [20]. The visual registration of the adhesion process was done by incubation fixed cells on a glass slide over $60 \mathrm{~min}$ and followed by washing with saline [20]. To the DNA-Gd immobilized cells dispersion was added a calculated concentration of europium chloride $\left(\mathrm{EuCl}_{3}\right) 5 \times 10^{-}$ [14] M in a solution of CLCD-Gd. After 60 min of the incubation period, the cells were once again washed with saline to remove unbounded CLCD-Gd particles. Fluorescent microphotograph of CLCD and cells with immobilized particles were registered using the fluorescent Nano scope (LLC "Stereonik," Russia) at the wavelength $\lambda-340 \mathrm{~nm}$ (fig. 3.) [21].

\section{Neutron-activated analysis of CLCD-DNA-Gd complex}

The samples containing DNA CLCD-Gd complex were activated using the neutron complex NG-400 (Moscow meson factory, INR) with fast neutrons containing $14.8 \mathrm{MeV}$ energy. The density of the neutron flux at the sample was $2 \times 10^{9} \mathrm{~cm}^{-2} \mathrm{~s}^{-1}$, and the proportion of other neutron energy was less than $1 \%$. Each one of a test sample of the DNA-Gd was placed between the two normalized samples. For the normalization used pure gadolinium foil with $0.11 \mathrm{~mm}$ thickness (ORTEC Inc., Oak Ridge, USA). This configuration was made its possible to eliminate the distortion of the neutron flux activation patterns. The intensity of the $\gamma$-radiation was measured by coaxial germanium detector IGC-45 (ORTEC Inc., Oak Ridge, USA). [22]

Statistical analyses were performed using experimental data samples; $n-10$. Student factor (t-test) for automatic calculation used a computer program "Origin 98". The relative error of the measured value was $\pm 5 \%$ with a confidence level at 0.95 .

\section{RESULTS AND DISCUSSION}

In the fig. 1, was a demonstrated formation process of CLCD-DNA-Gd complex. The different $\mathrm{GDCl}_{3}$ concentration was used carried out complex formation process, and the formation process was determined using the appearance of $2^{\text {nd }}$ amplification in the circular dichroism spectrum (CD) of the CLCD-DNA-Gd complex. The $1^{\text {st }}$ curve in the diagram was demonstrated the absence of $\mathrm{GdCl}_{3}$.

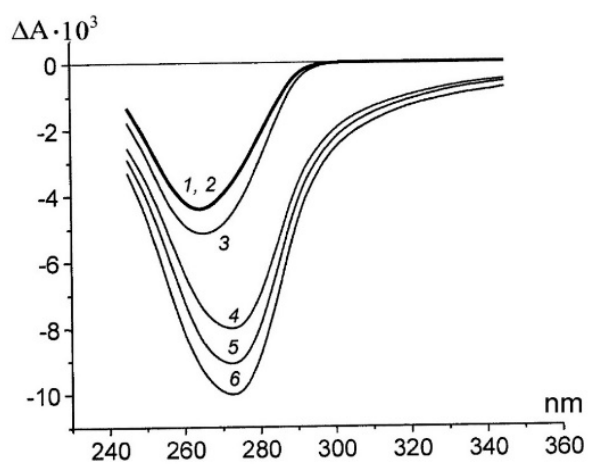

Fig. 1: Circular dichroism specter of CLCD-DNA, 1. in the absence of $\mathrm{GdCl}_{3}, 2-6-$ in the presence of $\mathrm{GdCl}_{3}, \Delta \mathrm{A}-\left(\mathrm{A}_{\max }-\mathrm{A}_{\mathrm{i}}\right), \mathrm{A}_{\max }=\sum\left(\mathrm{A}^{+-}\right.$ $A^{-}$), where, $A^{+}$-amplitude of absorption peak of dextrorotatory plane-polarized light, $\mathrm{GdCl}_{3}$ concentration: $2-2.49 \times 10^{-4}, 3-4.97$ $\times 10^{-4}, 4-9.8 \times 10^{-4}, 5-1.48 \times 10^{-3}, 6-2.92 \times 10^{-3}$

This data coincided with experiment data obtained Yevdokimov et al. In the experiment, was established, that the adding $2.49 \times 10^{-4} \mathrm{M} \mathrm{GdCl}_{3}$ was not affected to the circular dichroism spectrum $\left(2^{\text {nd }}\right.$ curve). Increasing amplitude of negative line of absorption spectra was monitored when the thevGdCl 3 concentration was $4.97 \times 10^{-4} \mathrm{M}\left(3^{\text {rd }}\right.$ curve). The maximum amplification was noticed in the concentration range $1 \sim 3 \times 10^{-3} \mathrm{M} \mathrm{GdCl}_{3}$ (4-6 curves). The experiments results were demonstrating the wellorganized structure of CLCD-DNA-Gd.

Study of interaction of double-stranded linear DNA with ions $\mathbf{G d}^{3+}$

The formation mechanism of CLCD-DNA-Gd complexes was identified by investigating the interactions of the gadolinium ions with a double-stranded DNA at various concentrations. Native DNAs were an incubated in water-salt solution $\left(3 \times 10^{-7} \mathrm{M} \mathrm{NaCl}\right)$ contains 
different concentrations of $\mathrm{GDCl}_{3}$ for one minute at room temperature. Fig. 2. was shown the variation of $C D$ spectrum of linear DNA solutions, which were incubated with various concentrations of $\mathrm{GdCl}_{3}$.

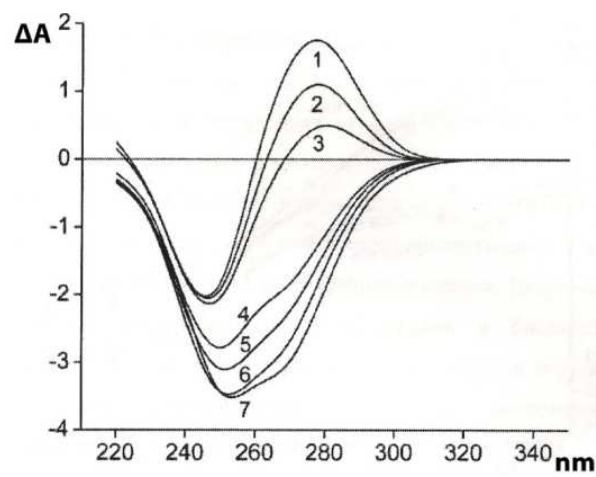

Fig. 2: Circular dichroism specter of CLCD-dsDNA, In the absence of $\mathrm{GdCl}_{3}, 2-6$-in the presence of $\mathrm{GdCl}_{3}, \Delta \mathrm{A}-(\mathrm{A}$ max-Ai), $\mathrm{A}$ $\max =\sum\left(A+-A^{-}\right)$, where, $A+-$ amplitude of absorption peak of dexter-rotatory plane-polarized light,, $A^{-}$-amplitude of absorption peak of sinister-rotatory plane-polarized light, Concentration $\mathrm{GdCl}_{3}, 2$ curve- $1 \times 10^{-5} \mathrm{M}, 3$ curve- $2 \times 10^{-5} \mathrm{M}, 4$ curve $-3 \times 10^{-5} \mathrm{M}, 5$ curve $-4 \times 10^{-5} \mathrm{M}, 6$ curve $-5 \times 10^{-5} \mathrm{M}$

The characteristic peak of the original B-form DNA (curve 7) was distorted at the higher concentration of gadolinium ions. The positive band at $\lambda-280 \mathrm{~nm}$ was changed its sign when the chloride concentration was reachedto $3 \times 10^{-5} \mathrm{M}$ and amplitude of the negative band was increased, and its maximum was shifted to length wave of the red region. The experimental results were demonstrated, that the CD spectrum changes of linear double-stranded DNA molecules when the $\mathrm{Gd}^{3+}$ ions presence may be caused by breach of a secondary DNA structure parameters. As a result of the very high affinity of DNA to the salts of rare earth metals at its nature, it was caused by the formation of ionic bonds between gadolinium and phosphate groups of the nucleic acid. These results (see fig. 3) were demonstrated, there was a transition of DNA structure from the Bform to Z-form when the interaction double-stranded linear DNA with the $\mathrm{GdCl}_{3}$. Sugar-phosphate backbone of the molecule was taken the zig-zag conformation, and these processes may be happened due to the appearance of clusters of positive charges on the external backbone of DNA with gadolinium, it was accompanied by the change of the DNA solubility.

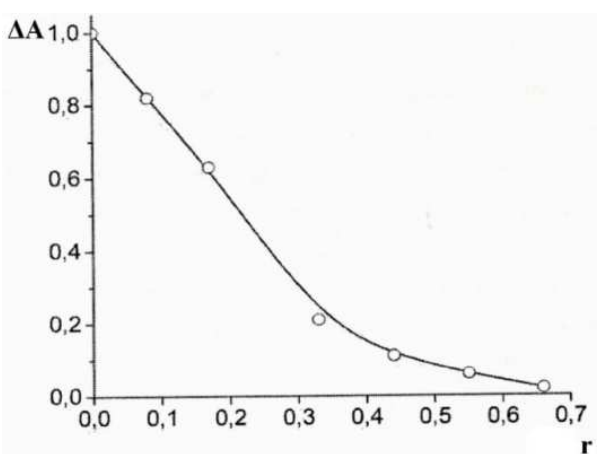

Fig. 3: Relative band amplitude $(\lambda-280 \mathrm{~nm})$ in the CD spectra of linear double-stranded DNA molecules on the value of $r_{\text {(total): }}$

$\Delta \mathbf{A}$ (ratio)- $\left[\mathbf{A}_{\max }-\Delta \mathbf{A}_{i}\right] /\left[\mathbf{A}_{\max }\right]$, wherein $\mathbf{A}_{\max }=\sum\left[\mathbf{A}^{+}-\Delta \mathbf{A}^{-}\right), \mathbf{A}^{-}$

amplitude of absorption peak of dextra-rotatory plane-

polarized light, $A^{-}$-amplitude of absorption peak of sinistrarotatory plane-polarized light. $\mathbf{r}_{\text {(total)c-ratio of }}$

$\mathrm{GdCl}_{3}$ concentration $(\mathrm{mol} / \mathrm{ml})$ to the basis DNA concentration $(\mathrm{mol} / \mathrm{ml})$ in the solution

\section{Study of formation of liquid crystalline dsDNA with ions $\mathbf{G d}^{3+}$}

To study the processes of formation of liquid crystals of doublestranded DNA (ds-DNA) was treated with $\mathrm{GdCl}_{3}$, ds-DNA was mixed with $0.9 \mathrm{ml}$ of DNA and $0.1 \mathrm{ml} \mathrm{GdCl}_{3}$ in the presence of PEG. The final concentration of gadolinium ions in the $1.0 \mathrm{ml}$ solution was related to $1 \times 10^{-5} \mathrm{M}, 2 \times 10^{-5} \mathrm{M}, 3 \times 10^{-5} \mathrm{M}, 4 \times 10^{-5} \mathrm{M}, 5 \times 10^{-5} \mathrm{M}$ and $6 \times 10^{-5} \mathrm{M}$. Then added $1.0 \mathrm{ml}$ of PEG solution $\left(9.5 \times 10^{-5} \mathrm{M}\right)$ and intensively stirred using a mixer over $3 \mathrm{~min}$. The mixture was incubated for one hour to form CLCD. CD spectrum was recorded every 5 min. Fig. 4. was shown the formed CD spectrum of CLCD-DNA pretreated with $\mathrm{GdCl}_{3}$. The spectrum was demonstrating that the formation of CLCD from linear ds-DNA treated with $\mathrm{GdCl}_{3}$ was accompanied by the disappearance of minus sign the abnormality peaks at $\lambda$ max -270 $\mathrm{nm}$ in the CD spectrum, which was characterized for the CLCD-DNA without pretreated by $\mathrm{GdCl}_{3}$.

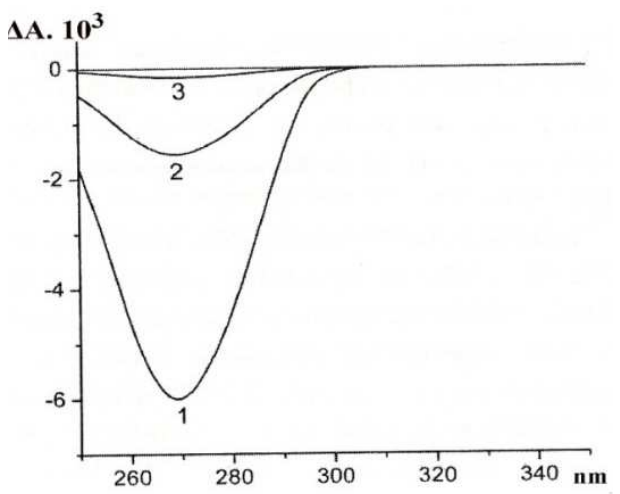

Fig. 4: CD spectra of formed CLCD, from DNA molecules, pretreated with aGdCl ${ }_{3}$ solution; $A=\left(A_{L}-A_{R}\right)$. Curve 1-CLCD in the absence of $\mathrm{GdCl}_{3}$; Curves-2 and 3 , in the presence of $\mathrm{GdCl}_{3}$, $0.6 \times 10^{-5} \mathrm{M}$, and $1 \times 10^{-5} \mathrm{M}$ respectively

\section{Identification impurities in the CLCD-DNA-Gd solution}

It was known that the core properties of CLCD-DNA-Lanthanide nanoparticles were identical for all the Lanthanide (L) [24]. Europium $\left(\mathrm{Eu}^{3+}\right)$ was early employed as a fluorescent label at the emits range 340 $\mathrm{nm}$ to $618 \mathrm{~nm}$. In this wavelength range, DNA or polyethyleneglycol (PEG) do not absorb photon energy, and trace impurities of $\mathrm{Eu}^{3+i n}$ the liquid crystal dispersion were made it intensely fluorescent in the medium (fig. 3.). It was possible not only for visualizing the dispersion of saturated complexes of DNA-Gd and detects the "transitional" forms of the cholesterin particles into the amorphous.

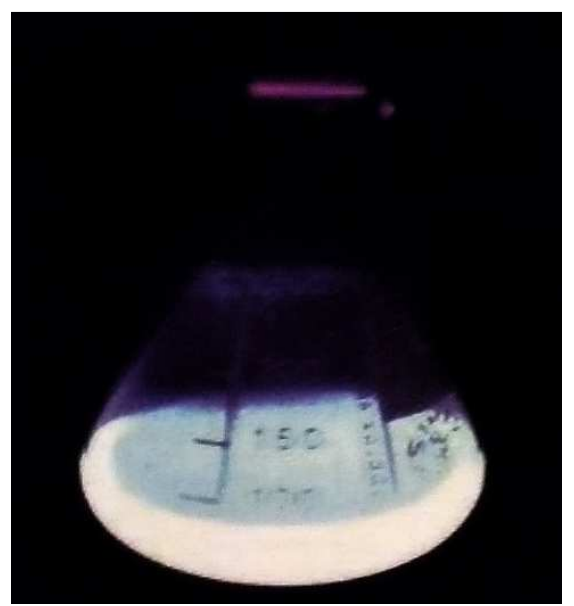

Fig. 3: CLCD-DNA-Gd medium intensely fluorescent, when presence $\mathrm{Eu}^{3+}$ as impurities 


\section{Visualization of CLCD-DNA-Gd nanoparticles}

As shown in [16], optical properties of CLCD-DNA were demonstrated about it's a liquid crystal structure. Cholesteric liquid crystal dispersion of DNA was formed at the phase deletion of DNA with PEG in the hyperosmotic solution. CLCD-DNA was a liquid particle with a diameter of about $500 \mathrm{~nm}$, was excluded from the phase of PEG-water. They were available in a concentration range of PEG 100 to $600 \mathrm{mg} / \mathrm{ml}$. Since double-stranded DNA molecules were polyphosphates, in sufficiently high concentration conditions of $\mathrm{Gd}^{3+}$ ion particles CLCD-DNA-Gd complexes were losing their solubility and acquired a surface charge, which prevented their aggregation. Previously, it was found, the gadolinium ions were binding with phosphate groups on the CLCD-DNA [25]. Therefore, as a result of the low solubility of the complex particles (solubility limit GdP04 10-[12]), were possible to study in the experiments by multiple washes and not in the initial solution with a high osmotic pressure. Indeed, tenfold dilution solution with water, after dilution this complex did not change its optical properties of dispersion [25].

It was important that the reaction of the hybrid organometallic CLCDGd nanoparticle with dsDNA-Gd liquid crystals were disappeared characteristic of the packing DNA molecules, and the properties of the particles became to a solid state. In support of this conclusion, can proved the existence of previously established Bragg peak at the X-ray reflex of CLCD-Gd [24]. The cause of reflexes obviously a rigid spatial structure of the matter. The liquid crystal dispersion without gadolinium did not possess Bragg peak. Interaction of DNA and $\mathrm{Gd}^{3+}$ ions have increased the attraction between the particles which were contained in the CLCD, caused by the effect of ionic cross-links [25]. This process can be seen in fig. 4, where the visible portion with stripes (like a fingerprint) typical for CLCD and an amorphous area characteristic to the solid precipitate of DNA-Gd.

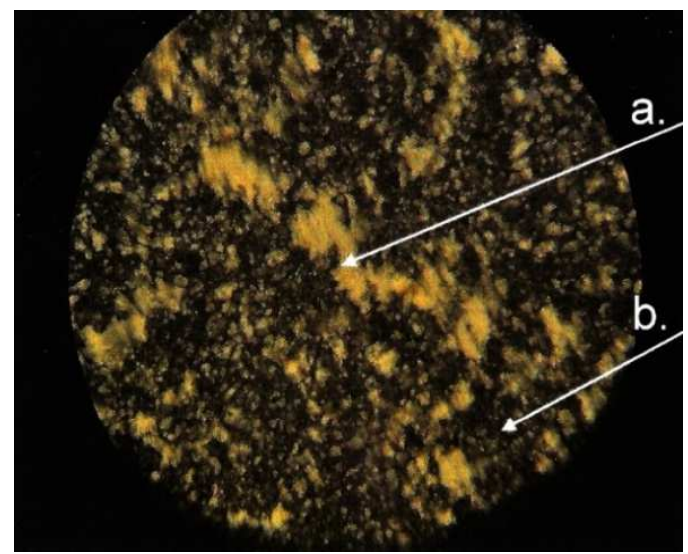

Fig. 4: Image of CLCD with the addition of $\mathrm{Gd}^{3+i o n s}$ in the field of view of a polarization microscope, a. The section with strips (such as "fingerprints"), b. Amorphous section (dark)

\section{Immobilization of CLCD-DNA-Gd with macrophages membrane}

Results of incubation of cells in the culture medium additive particles CLCD-DNA-Gd followed by washing were shown in fig. 5 . There were shown slide fixed with immobilized cells associated dispersion particles. The average size of the macrophages was related to $10-20 \mu \mathrm{m}$, and particles only $0.5 \mu \mathrm{m}$ (fig.5), the and it was the clearly visible proportion of the particles ratio to the macrophage size. The phenomenon of CLCD-DNA-Gd particles adhesion in cell membranes, presumably, can provide the basis for the development of a technique for the retention gadolinium in tumor tissue, until the neutrons irradiate it.

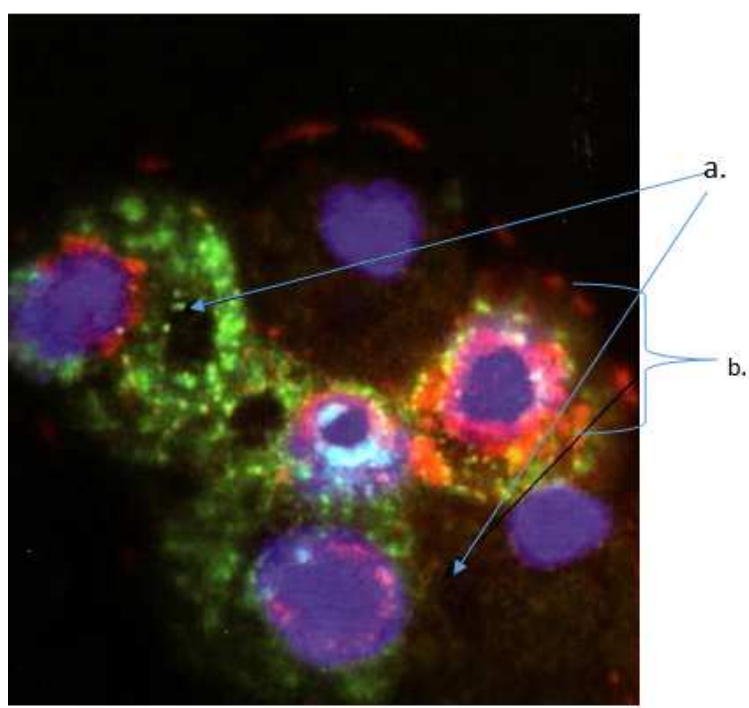

Fig. 5: The view of macrophages with attached CLCD (DNA-Gd) particles, a. Nanoparticles CLCD (DNA-Gd), b. Mice macrophages

Determination of gadolinium concentration in CLCD-DNA-Gd by the different analytical method

During the interaction of $\mathrm{Gd}^{3+}$ ions with molecules of double-stranded DNA fixed to the spatial structure of the liquid crystal dispersion with $\mathrm{Gd}^{3}+$ ions, the cholesteric dispersion structure was retained [16]. Quantitative determination of the concentrations of $\mathrm{Gd}^{3+}$ in obtained CLCD-DNA-Gd complexes was performed using atomic emission spectral analysis. Determination gadolinium concentration in samples of CLCD-DNA-Gd was performed by destructive chemical analysis method. In the analysis procedure, the test sample was subjected to ashing at $\sim 400^{\circ} \mathrm{C}$ temperature and followed by dissolving in $5.0 \mathrm{M}$ $\mathrm{HCl}$ solution; the admired solution was analyzed for Gd by atomic emission spectral analysis using spectrometer JY-38P (France). [18] The results were shown in table 1.

Table 1: Determination of concentration gadolinium in CLCD-DNA-Gd by different analytical method

\begin{tabular}{|c|c|c|c|c|c|c|}
\hline \multirow{2}{*}{\multicolumn{2}{|c|}{$\begin{array}{l}\text { Sample № } \\
\text { weight of } \\
\text { DNA (mg) }\end{array}$}} & \multicolumn{2}{|c|}{ Weights of gadolinium (mg) } & \multirow{2}{*}{$\begin{array}{l}\text { Average weight of } \\
\text { gadolinium } \\
\text { (mg) }\end{array}$} & \multirow{2}{*}{$\begin{array}{l}\text { Conc. } \\
\text { gadolinium } \\
\% \\
\end{array}$} & \multirow{2}{*}{$\begin{array}{l}\text { the relative concentration of } \\
\mathrm{GdCl}_{3} \\
(\mathrm{~mol} / \mathrm{ml})\end{array}$} \\
\hline & & $\begin{array}{l}\text { Activated } \\
\text { analysis }\end{array}$ & $\begin{array}{l}\text { Atomic-emission- } \\
\text { analysis }\end{array}$ & & & \\
\hline 1 & 0.943 & $0.79 \pm 0.07$ & $0.70 \pm 0.07$ & $0.745 \pm 0.06$ & 44.1 & 1.63 \\
\hline 2 & 0.995 & $0.77 \pm 0.10$ & $0.77 \pm 0.10$ & $0.77 \pm 0.10$ & 43.6 & 1.59 \\
\hline 3 & 0.590 & $0.47 \pm 0.06$ & $0.47 \pm 0.06$ & $0.47 \pm 0.06$ & 44.3 & 1.64 \\
\hline 4 & 0.295 & $0.17 \pm 0.03$ & $0.19 \pm 0.02$ & $0.19 \pm 0.02$ & 39.0 & 1.32 \\
\hline
\end{tabular}

$\mathrm{n}$-10 samples, all values represent mean $\pm \mathrm{SD}$

\section{The assessment of cytotoxicity of CLCD-DNA-Gd nanoparticles}

Toxicity of DNA-Gd dispersion was evaluated by a 40 -minute, $24 \mathrm{~h}$ and $72 \mathrm{~h}$ incubation periods. Cells $\left(1 \times 10^{6}\right)$ were placed in culture medium
RPMI-40 supplemented with $3 \times 10^{-4} \mathrm{M} \mathrm{Gd}^{3+}$. $\mathrm{Gd}^{3+}$ ions are introduced as $\mathrm{GdCl}_{3}$ or as a component of CLCD-Gd complex. The proportion of dead cells was calculated by a supravital staining method with $0.1 \%$ trepan blue solution [20]. The results were shown in table 2 . 
Table 2: Macrophages viability percentage over general count

\begin{tabular}{|c|c|c|c|}
\hline \multirow[t]{2}{*}{ Added to culture medium RPMI-40, when incubation } & \multicolumn{3}{|c|}{ Incubation period of macrophages } \\
\hline & $40 \mathrm{~min}$ & $24 \mathrm{~h}$ & $72 \mathrm{~h}$ \\
\hline Commercial culture medium RPIM-40 & $100 \pm 5$ & $98 \pm 5$ & $93 \pm 5$ \\
\hline $\mathrm{GdCl}_{3}$ & $40 \pm 2$ & $6.0 \pm 0.3$ & 0 \\
\hline CLCD-DNA & $100 \pm 5$ & $84 \pm 4$ & $72 \pm 3$ \\
\hline CLCD-DNA-Gd & $100 \pm 5$ & $93 \pm 5$ & $89 \pm 5$ \\
\hline
\end{tabular}

$\mathrm{n}-10$ samples, all values represent mean \pm SD

Atomic emission spectral analysis of the resulting supernatant and the cell membranes of treated cells and CLCD-DNA-Gd complex was showed that over $97 \%$ of the gadolinium was associated with cell membranes. This result implies that the CLCD-Gd particles were not only firmly fixed on the membrane, and penetrated little inwards. The particles have not express toxic effect. The remaining 3\% of gadolinium in a cell can be attributed to partial leaching cell sap by freeze-thaw, as well as the phagocytosis by the macrophages.
Indeed, the particles were built with foreign DNA may be itself to a target for phagocytes. Adding CLCD-DNA-Gd dispersion into a cell culture and subsequent incubation did not lead to a marked reduction in cell viability. However, the same concentration of $\mathrm{GdCl}_{3}$ was reduced viability to $40 \%$. This fact apparently was due to the fact, that gadolinium was securely held within the particles without eluted intercellular environment and did not penetrate into the cells via the ion channels.

Table 3: Macrophages viability after neutron irradiation

\begin{tabular}{|c|c|c|c|}
\hline \multirow[t]{2}{*}{ Samples } & \multicolumn{3}{|c|}{ Percentage of cell viability after irradiation } \\
\hline & $40 \mathrm{~min}$ & $24 \mathrm{~h}$ & $72 \mathrm{~h}$ \\
\hline Control sample & $95 \pm 5$ & $91 \pm 4$ & $86 \pm 4$ \\
\hline Cells+CLCD DNA & $95 \pm 5$ & $84 \pm 4$ & $72 \pm 3$ \\
\hline Cell+nanoparticles & 0 & 00 & \\
\hline nanoparticles & - & - & - \\
\hline Macrophages were incubated in thermostat & $100 \pm 5$ & $98 \pm 5$ & $93 \pm 5$ \\
\hline
\end{tabular}

$\mathrm{n}-10$ samples, all values represent mean \pm SD

The immediate impact of thermal neutrons on cells, confirms that the neutron flux interacts weakly with living tissues and can be considered a relatively safe [26]. Thus, in a single irradiation in control samples were appeared:

$95 \%$ of viable cells after 40 min of irradiation;

$91 \%$ of viable cells after $24 \mathrm{~h}$ exposure;
$86 \%$ of viable cells after $72 \mathrm{~h}$ exposures.

Cells with CLCD-DNA-Gd particles, with the standard concentration of $\mathrm{Gd}^{3+}$,was related to $3 \times 10^{-4} \mathrm{M}$; there was a $100 \%$ of cell deaths after irritation. Only a decrease in the concentration of particles in the dispersion 5 times was allowed to achieve $15 \%$ of cell survival after $40 \mathrm{~min}$, but further incubation led to cell death entirely.

Table 4: Cells viability with decreasing $\mathrm{Gd}^{3+}$ concentration

\begin{tabular}{llll}
\hline Gd $^{3+}$ conc. (mol/l) & Viability (\%) after incubation period of & \\
\cline { 2 - 4 } & $\mathbf{4 0 ~} \mathbf{~ m i n}$ & $\mathbf{2 4} \mathbf{~ h}$ & \\
\hline $3 \times 10^{-4}$ & 0 & 0 & 0 \\
$6 \times 10^{-5}$ & $15 \pm 2$ & 0 & 0 \\
$3 \times 10^{-5}$ & $20 \pm 2$ & 0 & 0 \\
\hline
\end{tabular}

$\mathrm{n}-10$ samples, all values represent mean $\pm \mathrm{SD}$

It was known, that the cell death caused not only conversion electrons, Auger electrons, the characteristic radiation, and gamma radiation, but also the simultaneous free-radical interaction caused by the reaction of photolysis of water and Cascade peroxidation [2527]. Therefore, the effectiveness of any drug, including CLCD-Gd particles, the radiation therapy was depended on a combination of many factors from local gadolinium concentration in the particles, the degree of absorption of secondary electrons and $\gamma$-rays within the particles themselves, on the biological effectiveness of radiation exposure on surrounding cancer cells, and others. [7-14, 27, 28].

The results were demonstrated that the particles with gadolinium could be fixed on the cells. Consequently, can expect that the phenomenon was described cell death would occur only in the radiation sites, and also locally. Moreover, the adhesion of particles on the cell surface allows retaining the drug inside the tumor until required irradiation time, which will allow reducing the dose of administering a gadolinium and the intensity of the neutron flux. In this experiment was obtained sufficiently chemically inert and stable preparation with a high local concentration of gadolinium was capable stored at room temperature for a year without losing their physicochemical properties [23]. The low solubility of the complex (SL 10-12), and the cells ability to survive at the simple incubation (without irradiation) in a medium with CLCD-Gd particles within 72hours was demonstrated the low cytotoxicity of the complex and also the drug safety. Due to cholesteric properties of the drug particles, the concentration of gadolinium was easily monitored by circular optical dichroism [1, 3, 15, 16, 22-24]. All these evidence provide a base to make a conclusion, the problem of the efficiency of neutron capture therapy when using ${ }^{157} \mathrm{Gd}$ can be successfully solved using the described method.

\section{CONCLUSION}

DNA-Gd nanoparticles were trapped effectively using described method in this experiment and successfully can be employed for the neutron flux irritation. Neutron capture was occurring in the particles with a high local concentration of ${ }^{157} \mathrm{Gd}$. The particles themselves were significantly chemically inert, and incubating the cells with precipitated particles thereon did not cause a significant 
toxic effect. Perhaps this fact will allow to reduce the time and dose of neutron radiation, as well as to reduce gadolinium concentration by several times.

The affinity of the particles for cell membranes (adhesion) allows on the cell point wise with greater intensity than individual atoms of gadolinium was one of the significant benefits of the drug compared to the other carriers of gadolinium. Radiation acts not only directly, "burning" of the membrane, DNA and the contents of the cytoplasm, but also switch on the free radical interaction. Continues extended period direct exposure in aggregate, there was a cumulative effect. Based on this experiment can make a conclusion, obtained CLCD-DNAGd nanoparticles can be recommended for using as agent for NCT.

\section{CONTRIBUTION}

We would like to declare here, Professor SLIVKIN A. I. has assisted the whole experiments process, under his assist KONDRASHINA O. V has carried out the experimental in Voronezh state university, BELENOVA A. S and HALAHAKOON M. A. J has contributed to data analyzing procedure and article preparation.

\section{CONFLICT OF INTERESTS}

Declared none

\section{REFERENCES}

1. Zakharov MA, Yevdokimov YuM, Skuridin SG. Nanotechnology based on nucleic acids. Proceedings RAS 2006;2:112.

2. Evathi Sundaramoorthy, Madhulatha Vuyyuru, Magharla Dasaratha Dhanaraju. Carbon nanotube: a flexible approach for nanomedicine and drug delivery. Asian J Pharm Clin Res 2015;8:25-31.

3. Zakharov MA, Yevdokimov YuM, Skuridin SG, NechipurenkoYuD. Nanotechnology based on spatially fixed ds DNA (RNA) molecules. Report of the OECD workshop on the safety of manufactured nanomaterials: Washington DC; 2005. p. 149.

4. Lafontaine I, Lavery R. Optimization of nucleic acid sequences. Biophys J 2000;79:680-5.

5. Yevdokimov YuM, Skuridin SG, Lortkipanidze GB. Invited article liquid-crystalline dispersions of nucleic acids. Liquid Cryst 1992;12:1-16.

6. Yevdokimov YuM, Salyanov VI, Zakharov MA. A novel type of microscopic size chip based on double-stranded nucleic acids. Lab Chip 2001;1:35-41.

7. Tokumitsu H, Ichikawa H, Saha TK, Fukumori Y, Block LH. Design and preparation of gadolinium-loaded chitosan particles for cancer neutron capture therapy. STP Pharma Sci 2000;10:39-49.

8. Goortley T, Zamenhof R, Nikjoo H. Calculated DNA damage from gadolinium auger electrons and relation to dose distributions in a head phantom. Int J Radiat Biol 2004;80:933-40.

9. Yasui LS, Andorf C, Schneider L, Kroc T, Lennox A, Saroja KR. Gadoliniumneutron capture in glioblastoma multiforme cells. Int J Radiat Biol 2008;3;84:1130-9.

10. Justin K Greisberg, Jennifer Moriatis Wolf, James Wyman, Lijun Zou, Richard M Terek. Gadolinium inhibits thymidine incorporation and induces apoptosis in chondrocytes. J Orthop Res 2001;19:797-801.

11. Tokumitsu H, Hiratsuka J, Sakurai Y, Kobayashi T, Ichikawa H, Fukumori Y. Gadolinium neutron-capture therapy using novel gadopentetic acid-chitosan nanoparticles: in vivo growth suppression of experimental melanoma solid tumor. Cancer Lett 2000;150:177-82.
12. Saha TK, Jono K, Ichikawa H, Fukimori Y. Preparation and evaluation of glutaraldehyde cross-linked chitosan microspheres as a gadolinium reservoir for neutron capture therapy. Chem Pharm Bull 1998;46:537-9.

13. Justin K Greisberg, Jennifer Moriatis Wolf, James Wyman, Lijun Zou, Richard M Terek. Gadolinium inhibits thymidine incorporation and induces apoptosis in chondrocytes. J Orthop Res 2001;19:797-801.

14. Leclercq F, Cohen-Ohana M, Mignet N, Sbarbati A, Herscovici J, Scherman D, et al. design, synthesis, and evaluation of gadolinium cationic lipids as tools for biodistribution studies of gene delivery complexes. Bioconjug Chem 2003;14:112-9.

15. Yuri Evdokimov. Liquid crystal forms of DNA and their biological role. Liquid Crystals 2003;3:10-47.

16. Yevdokimov YM, Salyanov VI, Kondrashina OV, Borshevsky VI, Semenov SV, Gasanov AA, et al. Particles of liquid-crystalline dispersions formed by (nucleic acid-rare earth element) complexes as a potential platform for neutron capture therapy. Int J Biol Macromol 2005;37:165-73.

17. Bekov GI Boitsov AA, Bolshov MA. Spectral analysis of pure substances, HI Silberstein. editor. SPb: Chemistry; 1994.

18. Lefkovits I, Pernis BV, Trucco M. Immunological research methods. M: Mir; 1988.

19. Adams RLP, Laboratory techniques in biochemistry and molecular biology. Vol. 8. NY: Elsevier; 1990.

20. Contribution adhesion on glass luminolchemiluminescence in whole blood stimulated by the addition of barium sulfate. Piryazev AP, Vladimirov YA, Sherstnev MP. II Congress of Russian biophysicists. abstracts. M. Research Institute of physicochemical medicine, theministry of health of the Russian Federation; 1999.

21. Klimov AA. Method of fluorescent nanoscopy. Patent RF № RU2305270C2; 2007.

22. Rima W, Sancey L, Aloy MT, Armandy E, Alcantara GB, Epicier $\mathrm{T}$, et al. Internalization pathways into cancer cells of gadolinium-based radiosensitizing nanoparticles. Biomaterials 2013;34:181-95.

23. Salyanov VI, Evseev AI, Popenko VI, Gasanov AA, Dembo KA, Kondrashin OV, et al. Some of the characteristics of gadolinium complexes with linear DNA and liquidcrystal forms. Biophysics 2007;52:452-9.

24. Evdokimov YuM, Salyanov VI, Nechipurenko JD. Molecular structure (superstructure) with controlled properties on the basis of double-stranded nucleic acids. Mol Biol 2003;37:340-55.

25. Nematovich KJ, Alekseevich KA, Influence of neutron capture therapy to biological subjects. Eur Sci Rev 2016;3:218-20.

26. Kudryashov Yu. Radiation Biophysics (ionizing radiation). M: Fizmatlit; 2003.

27. Podlyashuk EL. Application of radiotherapy in the treatment of non-neoplastic diseases, malignant and benign skin tumors. Radiol Practice 2000;3:41-3.

28. Jessy Shaji, Ipshita Menon. Recent advances in nanocarrier based therapeutic and diagnostic tools for colorectal cancer. Int J Curr Pharm Res 2015;7:9-16.

\section{How to cite this article}

- $\quad$ Slivkina I, Kondrashina OV, Halahakoon Maj, Belenova AS. DNAbased hybrid liquid crystalline nano organometallic composites for targeted drug delivery in neutron capture therapy. Int J Pharm Pharm Sci 2017;9(6):74-79. 